\title{
Thomas Pynchon and the Black Panther Party: Revolutionary Suicide in Gravity's Rainbow
}

\author{
JOANNA FREER
}

This article pertains to the recent upsurge of interest in the politics of Thomas Pynchon. It considers Pynchon as an author very much of the 1960s counterculture, and explores the countercultural values and ideals expressed in Gravity's Rainbow, with particular emphasis on revealing the novel's attitude to the Black Panther Party. Close textual analysis suggests Pynchon's essential respect for Huey P. Newton's concept of revolutionary suicide, and his contempt for Marxist dialectical materialism, two core elements of Panther political theory. Drawing on an analogy between the BPP and Pynchon's Schwarzkommando, an assessment is made of the novel's perspective on the part played by various factors - including the Panthers' aggressive militancy, the rise of Eldridge Cleaver through the leadership, and the subtle influence of a logic of power influenced by scientific rationalism - in bringing about the disintegration of the Panther organization by the early I 970 . Given the similarities between the paths taken by the BPP and the wider counterculture in the late 1960s, the article considers Pynchon's commentary on the Panthers to be part of a cautionary tale for future revolutionaries fighting similar forms of oppression.

Through his novels and journalism Thomas Pynchon has repeatedly demonstrated a deep interest in African and African American culture and history, and has spoken out against both past colonial atrocities and presentday racial discrimination. As an author who produced his first mature work in the I 960 s, Pynchon's interest in racial oppression is rooted in his experience of that unruly decade. It must also be seen as part of a broader political agenda to critique all forms of oppression, an agenda which reflects Pynchon's sympathy with core New Left and counterculture values. Expressed perhaps most directly in "A Journey into the Mind of Watts" (1966), an article Pynchon wrote for the New York Times Magazine in which he explores the causes of the incendiary riots of the previous summer and defends the actions of the inhabitants of Watts, this affinity for revolutionary ideals remains highly visible throughout his literary career to date, as in the anarchist current running through Against the Day (2006), and in the characteristically i 960 sera social criticism of Inherent Vice (2009). This article explores some

Department of History, Art History and Philosophy, University of Sussex. Email: joanna_freer@hotmail.com. 
important aspects of Pynchon's countercultural sensibility as expressed through certain sections of perhaps his most "sixties" novel, Gravity's Rainbow (1973): his respect for black protest organizations, his attitude towards the turn to violence taken by some such groups and by the counterculture more generally in the late 1960 s, and his assessment of the forces to blame for the general demise of the counterculture movement by the early i 970 s. This will be achieved via an analysis of Gravity's Rainbow's commentary, discernible amongst the myriad political perspectives and positions in the novel, upon the most notorious of the revolutionary black rights groups, the Black Panther Party (BPP).

Founded in Oakland, California in 1966 by Huey P. Newton and Bobby Seale, the Black Panthers aimed to protect and gain autonomy for African American communities within the United States; their ten-point "Platform and Program" demanded, among other things, freedom, employment, decent housing and an end to police brutality. ${ }^{1}$ Far from desiring equality within the capitalist system as earlier civil rights activists had, the Panthers perceived the capitalist ethos as a key cause of racism in America. ${ }^{2}$ Describing themselves as Marxist-Leninists and strongly influenced by contemporary communist leaders such as Mao Zedong of China and Fidel Castro of Cuba, the Panthers' ultimate aim was a total communist revolution in American society. "Survival Programs" such as free community breakfasts and transport services for prison visitors were at the centre of the BPP's attempts to liberate black citizens from the worst effects of white oppression. Yet the organization gained fame not through such community programmes but as a result of the particularly sensational images of the Panthers, dressed in military-style uniforms and brandishing shotguns, that circulated in the national news media. The firearms they carried were a practical application of the teachings of the late Malcolm $\mathrm{X}$, intended to enable self-defence against the LAPD, ${ }^{3}$ and the military uniform was intended to underscore the group's professionalism and unity. ${ }^{4}$ The BPP appealed to the white left of the late 1960 s, both in making "vivid" the idea of revolution, ${ }^{5}$ and in their ability to embody simultaneously several

${ }^{\text {I }}$ Black Panther Party, "The Black Panther Party: Platform and Program," in J. C. and S. E. Albert, eds., The Sixties Papers: Documents of a Rebellious Decade (New York: Praeger, 1984), 1 59-64. Reprinted from The Black Panther, 5 July 1969.

${ }^{2}$ See Huey P. Newton, Revolutionary Suicide (New York: Harcourt, Brace, Jovanovich, 1973), 70. Subsequent references to this edition are made parenthetically within the text.

${ }^{3}$ Charles E. Jones and Judson L. Jeffries, “Don't Believe the Hype': Debunking the Panther Mythology," in Charles E. Jones, ed., The Black Panther Party [Reconsidered] (Baltimore: Black Classic Press, 1998), 25-55, 27.

${ }^{4}$ Henry Hampton and Steve Fayer, Voices of Freedom: An Oral History of the Civil Rights Movement from the I9sos through to the Ig80s (London: Vintage, 1995), 351.

s Todd Gitlin, The Sixties: Years of Hope, Days of Rage (New York: Bantam Books, I 993), 348. 
currents within the white left; as Todd Gitlin points out, "In the person of the Panthers...the anarchist impulse could be fused with the Third World mystique, the aura of violence, and the thrust for revolutionary efficiency." 6 Unfortunately, however, the group's aggressive image and militant stance did little to endear them to either the general public or the federal government, and a huge FBI counterintelligence operation was targeted at the group, employing tactics of infiltration, murder and misinformation. This, combined with other factors, meant that by $197 \mathrm{I}$ the organization had been virtually wiped out.

The BPP are a current interest in Pynchon's work, appearing in his most recent novel Inherent Vice. Here, the protagonist, Doc Sportello, declaims the FBI's attempts to undermine the organization by generating conflict with other black rights groups (specifically Ron Karenga's US). ${ }^{7}$ In Gravity's Rainbow, an analogy between the fictional black rocket corps known as the "Schwarzkommando" and the Black Panther Party has attracted previous critical attention, particularly from David Witzling in his groundbreaking study on race in Pynchon, Everybody's America (2008). Yet that Pynchon was thinking of the Panthers while writing Gravity's Rainbow has so far been a matter, essentially, of speculation, as the group is not named within the novel either directly or in partially veiled fashion (as Malcolm X is in the figure of Red Malcolm). Like everything else in this novel, the Schwarzkommando are multi-referential; their narrative certainly encodes a number of commentaries upon the particular exigencies of the Second World War Europe they inhabit, larger global themes and issues such as the legitimacy of leadership in religious and political contexts, and the contemporary sociopolitical landscape of late I 960 s and early I970s America in which Pynchon was writing. Yet towards the end of Gravity's Rainbow there lies a passage, previously neglected in criticism, which establishes virtually beyond doubt the presence of the BPP within Pynchon's great novel. It is a conversation which occurs between the Russian Marxist Vaslav Tchitcherine and the German corporate spy Wimpe. Their dialogue revolves around the value of revolutionary suicide as a form of political activism, a concept peculiar to the Black Panther Party and anachronistic in the Second World War context of Gravity's Rainbow. Moreover, they debate "Marxist dialectics" - by which we understand dialectical materialism ${ }^{9}$ - an approach which was adopted by the Panthers

\footnotetext{
${ }^{6}$ Ibid., 350.

7 Thomas Pynchon, Inherent Vice (London: Jonathan Cape, 2009), 75.

${ }^{8}$ Thomas Pynchon, Gravity's Rainbow (London: Vintage, I995; first published 1973), 70 I. Subsequent references to this edition are made parenthetically within the text.

${ }^{9}$ Dialectical materialism is one of the central tenets of Marxist thought, although neither Marx nor Engels used the term themselves, it being applied by later interpreters of their work. Essentially a materialist reconception of Hegel's idealist dialectics, dialectical materialism
} 


\section{Joanna Freer}

and became an integral part of their political theory. The passage thus acts as a commentary upon both the ideology and the methodology of the BPP, as well as on Marxism more generally.

Revolutionary suicide was arguably Huey P. Newton's best-publicized concept and, given his role as co-founder, leader and "chief theoretician" of the $\mathrm{BPP}$, is to be considered part of the official party line. ${ }^{\circ}{ }^{\circ}$ Often misinterpreted as evincing a "death wish," ${ }^{11}$ revolutionary suicide is essentially the willingness to risk death in the struggle against oppression and to improve the lot of one's community. Newton was vocal in advocating this idea at the height of the Panthers' influence, before publishing a formal written theorization of revolutionary suicide in his autobiography of the same name. ${ }^{12}$ Drawing on Emile Durkheim's study Suicide and another by Dr. Herbert Hendin on black suicide rates in America, in Revolutionary Suicide Newton distinguishes two types of suicide. The first is "reactionary suicide," which he describes as "the reaction of a man who takes his own life in response to social conditions that overwhelm him and condemn him to helplessness" $\left(R S_{4}\right)$ - conditions such as those, Newton argues, confronted by black people in contemporary American society. With "revolutionary suicide," on the other hand, "Although I risk the likelihood of death, there is at least the possibility, if not the probability, of changing intolerable conditions" $(R S 5)$.

The conversation which is the focus of our present discussion begins when Tchitcherine brings up what the narrator describes as "political narcotics" (GR 70I), otherwise known as "[o]piates of the people," an allusion, of course, to Marx's famous statement that religion "is the opium of the people." 13 The use of the plural "opiates" indicates that we are not merely discussing religion here, but all means by which people might distance themselves from what others would consider real. Tchitcherine argues that "Marxist dialectics" is the "antidote" (GR $70 \mathrm{I})$ to such opiates, a means of

considers the movement of history to occur as a result of material factors, developing in stages as successive revolutions impel society towards communism. For a detailed description of dialectical materialism and its genesis see (e.g.) Paul Thomas, Marxism and Scientific Socialism: From Engels to Althusser (New York: Routledge, 2008), 86-105.

${ }^{10}$ Newton is described thus in The Huey P. Newton Foundation, The Black Panther Party: Service to the People Programs, ed. David Hilliard (Albuquerque: University of New Mexico Press, 2008), I 29.

${ }^{11}$ As Newton himself notes in Revolutionary Suicide, 5.

${ }^{12}$ This was published in 1973, the same year as Gravity's Rainbow. The concept of "revolutionary suicide" had already been publicized, however, via an edited collection of Newton's writings, To Die for the People, released in 1972, and via Newton's prison interviews which were published on Paredon Records in Jan. 1970.

${ }^{13}$ Karl Marx, Critique of Hegel's "Philosophy of Right", ed. Josephy O'Malley, trans. Annette Jolin and Joseph O'Malley (Cambridge: Cambridge University Press, 1977; first published I 843), I 3 I. 
logically cutting through veils of illusion and getting at the truth of the situation. Wimpe's counterargument is that Marxist dialectics is just another one of the political narcotics in question, offering a means for one group to gain power over another. Having momentarily silenced Tchitcherine with this point, a cynical Wimpe smiles "an old, old smile to chill even the living fire in Earth's core" and goes on to "lay it right out for the young fool":

"The basic problem," he proposes, "has always been getting other people to die for you. What's worth enough for a man to give up his life? That's where religion had the edge, for centuries. Religion was always about death. It was used not as an opiate so much as a technique - it got people to die for one particular set of beliefs about death. Perverse, natürlich, but who are you to judge? It was a good pitch while it worked. But ever since it became impossible to die for death, we have had a secular version - yours. Die to help History grow to its predestined shape. Die knowing your act will bring a good end a bit closer. Revolutionary suicide, fine. But look: if History's changes are inevitable, why not not die? Vaslav? If it's going to happen anyway, what does it matter?" (GR $70 \mathrm{I}$ )

Tchitcherine's argument reflects Newton's standpoint on dialectical materialism. Specifically, Newton argued that dialectical materialism was highly rational and effective in its linking of the Kantian concept of "rationale," or pure reason, with the established rules for the empirical observation of phenomena. In a "historic" speech delivered at Boston College in November 1970, ${ }^{14}$ Newton explained,

If, like Marx, we integrate these two concepts or these two ways of thinking, not only are we in touch with the world outside us but we can also explain the constant state of transformation. Therefore, we can also make some predictions about the outcome of certain social phenomena that is not only in constant change but also in conflict. ${ }^{15}$

Dialectical materialism was a means of reliably predicting future events for Newton, including the revolution to come. In the same speech, he argued that improvements in technology would lead to a "technocracy" in America. Technological innovations would cause the lumpenproletariat, those jobless outcasts from the American social system, to swell massively. From the thesis of technological development, through the antithesis of a growing force of discontented unemployed, Newton reached the synthesis: the revolution of the lumpenproletariat. ${ }^{16}$ From the perspective of the early twenty-first century, the flaw in Newton's logic is clear: he failed to consider how the technocracy might seek to prevent or remedy the situation.

${ }^{14}$ The speech is described in this way in Kathleen Cleaver and George Katsiaficas, eds., Liberation, Imagination and the Black Panther Party: A New Look at the Panthers and Their Legacy (New York: Routledge, 200I), 27.

${ }^{15}$ Huey P. Newton, "Speech Delivered at Boston College," i 8 Nov. 1970, in The Huey P. Newton Reader, ed. David Hilliard and Donald Weise (New York: Seven Stories Press, 2002), $160-75,163$.

${ }^{16}$ Ibid., 166. 


\section{I76 Joanna Freer}

I suggest that Pynchon mistrusted the logic of Marxist dialectical materialism from the start in its very presumption of a predictable future, but also in its vision of revolution as the archetype of historical "synthesis." Gravity's Rainbow's "Counterforce" (a group whose dates, 1966-71, match those of the BPP, and who talk about "The Man" in a very similar way ( $G R$ 7I2)) fail to achieve their objectives; at this historical juncture Pynchon's novel, unsurprisingly, represents revolution as a highly unlikely eventuality. This logically makes it all the more imperative that revolutionary movements perceive the difficulty of achieving their goal, thus putting the onus on each individual to help make it happen. Through the Wimpe-Tchitcherine dialogue, then, two problems with dialectical materialism's representation of revolution as predictable and inevitable are demonstrated. The first is encapsulated in Wimpe's formulation that "if History's changes are inevitable, why not not die?" Self-sacrifice becomes hard to defend in the context of a predictable future. In the specific case of the Panthers, Wimpe's comment reveals their two core ideological concepts, revolutionary suicide and dialectical materialism, to be essentially conflictual. The confusion caused by attempting to combine these concepts is evident in Newton's Boston College speech, in which he argued that when the Panthers "are using the method of dialectical materialism we don't expect to find anything the same even one minute later because 'one minute later' is history." ${ }^{17}$ Newton intended to show by this that the party were strongly aware of the constantly shifting parameters of the historical situation in their use of the dialectical materialist method, and would therefore not sink into complacent inactivity. What I would argue is that this confusion of aims demonstrates that the strength of Newton's commitment to revolutionary suicide, to purposive action of this kind, was superior to his commitment to the dialectical method. But his attempt to retain, within the dialectical method, both the idea that the world is in a state of constant flux, and the predictive element, exposes the central problem with the modern use of dialectics.

Modern dialecticians have, in fact, perverted dialectics from a method of rational argument (in which an awareness of the ever-changing flux of life was valuable) into a method of prediction. Clearly, a method for predicting the future on the basis of fixed material variables cannot function when such variables are allowed to change from one minute to the next. In making dialectics predictive, modern thinkers have turned a search for truth which, in its dualism, worked against rhetoric and control, into a theory by mastering which they can claim a logically valid basis for making predictions about the future. The apparently incontestable authority this can lend to revolutionary

${ }^{17}$ Ibid., I 65. 
leaders is the second problem with the dialectical method Pynchon highlights. Josef Stalin, to take a powerful example, in elaborating his "diamat" interpretation of dialectical materialism, gained thereby some of the authority he used to maintain his despotic rule over the Soviet Union. And we can only suppose that in making predictive dialectical materialism central to their ideology, the Panther leaders also hoped to gain a level of command over their people. It would make sense that, in a society dominated by scientific rationalism, the need was felt for a theory seen as serious, logical and having universal application. By using dialectical materialism, Newton perhaps aimed to confer such qualities onto a group considered by the general public dangerously irrational and having narrowly race-oriented interests. But employed in this way, the theory clearly goes against the utopian, egalitarian ethos Newton developed in his doctrine of revolutionary suicide. Instead, it allies itself with the innately masculinist, authoritative self-image the BPP initially aimed to promote through wearing uniforms, reading from law books and carrying firearms. As noted above, this authority-seeking, aggressive attitude-although adopted to facilitate self-defence-contributed to the Panthers' downfall.

The potentially pernicious nature of the dialectical materialist approach receives further attention in a scene which appears much earlier in the novel, in which Pynchon's narrator launches into a diatribe against Marx, describing him as a "sly old racist" (GR 317). This attack occurs in the midst of a discussion of the colonial persecution of the native Herero population in German South West Africa. Amid a vision of a colony left as "[j] ust a big hunk of desert," a mirage of Marx appears, "skipping away with his teeth together and his eyebrows up trying to make believe it's nothing but Cheap Labor and Overseas Markets" (GR 3 17). The rationale of the narrator's attack on Marx in this section most probably stems from Marx's treatment of colonial regimes as a necessary evil on the road to communist revolution. In an article published in the New-York Daily Tribune in I 853, Marx discussed the British colonial regime in India, taking pains to point out its brutality and destructive near-sightedness, but ending with a quotation from Goethe which reads: "Sollte diese Qual uns quälen / Da sie unsre Lust vermehrt?" (Should this torture then torment us / Since it brings us greater pleasure?). ${ }^{18}$ Marx's argument is essentially that colonialism is an integral part of capitalism and since capitalism must reach its predestined shape before the communist revolution can occur, then its evils are something that must be endured. The dialectical materialist method leads Marx to an oversimplistic view of what colonies actually are (far more than "Cheap Labor and Overseas Markets"),

\footnotetext{
${ }^{18}$ Karl Marx, "The British Rule in India," New-York Daily Tribune, 25 June r853, 5.
} 


\section{Joanna Freer}

which in turn allows him to effectively sanction the imperialist exploitation he claims to abhor. A third problem with dialectical materialism is thus demonstrated: it allows even highly intelligent people like Marx to find justifications for human suffering. In a very similar vein, Lawrence Wolfey has claimed that Pynchon rejects Marxism because "its materialism ignores the fact that the world is a projection of spirit, and its much touted dialectical method is merely a cover for a perverted millennialism, itself an excuse for totalitarian structures." ${ }^{2}$ This explains why Weissmann, probably the most negative character in the novel, has a "dialectical Tarot" whose product, created via some "Marxist-Leninist magicians," is "a new kind of demon" (GR 748). Against the Day contains further evidence of an antimaterialist Pynchon in its attraction towards "the beyond" in various guises, and in its approving nod to the Otzovist strain of Marxism. ${ }^{20}$

However, while the author would seem to agree with Wimpe that Marxist dialectics often functions as an opiate of the people, Gravity's Rainbow does not promote the idea that self-sacrifice for a revolutionary cause is entirely worthless. Tchitcherine may be a "young fool" for one with such mercenary motivations as the corporate spy Wimpe, but he is not entirely so for Pynchon. Newton argues, in a formulation reminiscent of the speeches of Dr. King, that the revolutionary suicide is a "fool," a fool for the revolution in the way that Paul meant when he spoke of being "a fool for Christ." That foolishness can move the mountain of oppression; it is our great leap and our commitment to the dead and the unborn. ( $R S$ 333)

Tchitcherine's logic may betray the naivety of an overoptimistic idealism (a naivety Newton celebrates in the above quotation), but Wimpe's earth-chilling wisdom is that of the selfish, coldhearted oppressors. While maintaining a clear sense of the practical difficulties of effecting any revolution, it seems evident that Pynchon's sympathies, if not his faith, would lie with the idealist in such a contest.

That Pynchon's interest in the Panthers attached itself primarily to the concept of revolutionary suicide is manifested by its thematic recurrence in Gravity's Rainbow, particularly in the Schwarzkommando sections discussed below. The ethos behind the concept of revolutionary suicide is something I suggest resonates with attitudes towards political revolt expressed in many of Pynchon's works. Even its violence can be justified in the terms with which

\footnotetext{
${ }^{19}$ Lawrence C. Wolfey, "Repression's Rainbow: The Presence of Norman O. Brown in Pynchon's Big Novel," PMLA, 92, 5 (Oct. 1977), 873-89, 878.

${ }^{20}$ A group called the "Otzovists" appears in Against the Day. The historical Otzovists were a Marxist faction with anarchist and humanist leanings who split from Lenin's Bolsheviks. In Against the Day they are believers in the fourth dimension and as such they are "antiMaterialist." See Thomas Pynchon, Against the Day (London: Vintage, 2007), 692-93.
} 
Pynchon defends the actions of rioters in "A Journey into the Mind of Watts." Here Pynchon considers the overt violence of the retaliatory act preferable to the sublimated violence of the American corporate system. In a related article, Kathryn Hume has suggested that, "if only out of despair over lack of effective peaceful alternatives," Pynchon seems to support political aggression in Against the Day. ${ }^{21}$ Yet her thesis of an increasingly aggressive Pynchon overlooks the Watts article, focussing instead for an example of this sentiment in embryonic form on the "minor character" Father Rapier's suggestion in Gravity's Rainbow that "They" (whom Hume defines as "the Elect, plutocratic owners of technologies and industries") must be killed, because "[o]nce the technical means of control have reached a certain size, a certain degree of being connected one to another, the chances for freedom are over for good." ${ }^{22}$ This article thus extends Hume's analysis, suggesting that political violence was a definite contender for Pynchon on the spectrum of political alternatives well before the publication of Gravity's Rainbow.

In "A Journey," Pynchon contends that in Watts "violence is never far from you: because you are a man, because you have been put down, because for every action there is an equal and opposite reaction." ${ }^{23}$ In this environment forces clash in comprehensible ways, as if according to physical laws. But for the "innocent, optimistic child-bureaucrats" who inhabit the "well-behaved unreality" of the corrupted corporate power system, violence becomes "an evil and an illness, possibly because it threatens property and status they cannot help cherishing." ${ }^{24}$ Expressing their lust for power through mediated acts of aggression, the "child-bureaucrats" could never count as "men." So when Wimpe, true to his name, denies that he could bring himself to sacrifice his life for any cause, he represents the cowardly hypocrisy of "Whitey, who knows how to get everything he wants, no longer has fisticuffs available as a technique, and sees no reason why everybody shouldn't go the Niceguy route." 25

Motivated by a very similar sense of exitless oppression, Newton's revolutionary suicide can be seen as an organized, institutionalized manifestation of the kind of violence Pynchon sanctions in Watts, its aim being always to prevent further violent acts in the future. Grasping at the only leverage left to a group bereft of economic power, the revolutionary suicide contends with the charade of political choice Herbert Marcuse, spokesman for the new left, describes in One-Dimensional Man (1964). The complex of values behind the theory represents a condensation of what Pynchon appears

\footnotetext{
${ }^{21}$ Kathryn Hume, "The Religious and Political Vision of Against the Day," Philological Quarterly, 86, I-2 (Winter 2007), I 63-87, I 64.

${ }_{22}^{2}$ Ibid., I 82, quoting GR 539, italics Pynchon's.

${ }^{23}$ Thomas Pynchon, "A Journey into the Mind of Watts," New York Times Magazine, I 2 June I 966,82 .

${ }^{24}$ Ibid., 84 .

${ }^{25}$ Ibid., 84 .
} 
to have respected in the philosophy of the counterculture, namely its deep sense of continuity and identity between people. As Newton explains in the epilogue to Revolutionary Suicide, "There is an old African saying, 'I am we.' If you met an African in ancient times and asked him who he was, he would reply, 'I am we.' This is revolutionary suicide: $\mathrm{I}$, we, all of us are the one and the multitude" ( $R S$ 332). In this sense, revolutionary suicide converges with the truly heroic act. However, although its core ethos is undeniably to be respected, Pynchon's commentary is far from suggesting unqualified support for revolutionary suicide.

Like Marcuse, Pynchon may well question the ultimate value of such desperate action. In Counterrevolution and Revolt (1972) Marcuse argues,

Martyrs have rarely helped a political cause, and "revolutionary suicide" remains suicide. And yet, it would be self-righteous indifference to say that the revolutionary ought to live rather than die for the revolution - an insult to the Communards of all times ... But then, the desperate act may have the same result - perhaps a worse result. One is thrown back to the inhuman calculus which an inhuman society imposes: weighing the number of victims and the quantity of their sacrifice against the expected (and reasonably expectable) achievements. ${ }^{26}$

Risking one's life for the good of one's people demonstrates a commitment to the community greater, even more idealistic than many white exponents of the counterculture were willing to take on. In 1973 it is unclear whether Pynchon would actually have supported the idea of one individual sacrificing themselves for the good of the group, but later in his career he voices a position on this a little more plainly. In Against the Day, for example, Frank, Stray and her son Jesse flee the miners' strike which is being broken up by the owners' hired militia. To stay in the encampment would mean certain death, but Jesse objects to their escape on the grounds that "Cowards run away." Frank, having achieved a certain wisdom via some hard-won life experience, responds, "Sometimes they're just not brave enough to run." ${ }^{27}$

Unfortunately, the doctrine of revolutionary suicide failed to reach the people in the pure form described above. A perspective on how theory failed to coincide with practice can be found, again, in the Wimpe-Tchitcherine dialogue. As the dialogue progresses, Wimpe's criticism of dialectical materialism subtly merges into a criticism of revolutionary suicide. This must be read as referring, anachronistically, directly to the Black Panthers' unique combination of the two concepts, because, although Wimpe's critique here is directed against a Marxist opponent, revolutionary suicide is not a concept

\footnotetext{
${ }^{26}$ Herbert Marcuse, Counterrevolution and Revolt (Boston, MA: Beacon Press, 1972), 52-53. Marcuse's use of the term "revolutionary suicide" here is not original, but refers to Newton's theory. The larger context of the quoted passage is a discussion of the contemporary oppositional practices of the new left.

${ }^{27}$ Pynchon, Against the Day, I 140.
} 
that appears within traditional Marxism in any form. Wimpe's criticism culminates with the formula "Die knowing your act will bring a good end a bit closer. Revolutionary suicide, fine" (GR $70 \mathrm{I}$ ). This could be reformulated as "Commit revolutionary suicide to help prove the theory of dialectical materialism." In its heroic sense, revolutionary suicide could be seen as a pure dialectical act, risking everything to push the dialectic forward towards the hoped-for revolution. As such, it would work against the problems of dialectical materialism, privileging practice over theory, faith over logic, and leaving no room for the self-interested individual to accumulate authority. But Wimpe's argument suggests that within the Black Panther Party the use of dialectical materialism in fact undermined the concept of revolutionary suicide. By having Wimpe merge the two concepts in such a way, the novel implies that by combining revolutionary suicide with a dialectical materialism whose goal was to garner power and authority for the leadership, the Panthers unwittingly set up the former to be perceived by the general public as just another way of "getting other people to die for you."

As noted above, the commentary on the Black Panther Party we see developing here is further extended through the Schwarzkommando plotline, which deals with the attempts of a militant faction of "Zone-Herero" to right the wrongs committed against them in their homeland of South West Africa. Predominantly first-generation descendants of the few Herero who survived the German imperial regime in Südwest, the Zone-Herero have arrived in Europe by a variety of routes. In 1945, they have somehow coalesced to form a community inhabiting a network of mineshafts close to the Mittelwerke, the wartime centre of German V-2 rocket production. Their aim is to reconstruct a $\mathrm{V}-2$ rocket from pieces of exploded $\mathrm{V}-2 \mathrm{~s}$ scavenged from around the Zone. The ultimate target of this rocket is unclear; its firing will be primarily a symbolic act through which the leader of the Schwarzkommando, Oberst Enzian, hopes to facilitate a spiritual-tribal homecoming of sorts. He believes that while the rocket itself is bound to (Western, linear) time, its launch will return his people to "the Center without time" (GR 319).

The Schwarzkommando have received various critical interpretations, but I would agree with Frederick Ashe in his assertion that as "an African population forcibly imported to be exploited by a white nation, then hysterically oppressed when its usefulness runs out and it gains a measure of autonomy, the Schwarzkommando obviously pertain more to the United States than to the Germany Pynchon fictionalizes." ${ }^{28}$ The relevance of the group to discussions of a civil rights context in Gravity's Rainbow is at least

\footnotetext{
${ }^{28}$ Frederick Ashe, "Anachronism Intended: Gravity's Rainbow in the Sociopolitical Sixties," Pynchon Notes, 28-29 (1991), 55-75, 67.
} 


\section{82 Joanna Freer}

twofold. Perhaps most directly, their presence as a black-only unit recalls Second World War controversies over segregation within the US armed forces, a key issue in revealing the hypocrisy of America's ongoing role as defender of the "free world" and in feeding the sense of domestic injustice which was so important in uniting the African American population behind the civil rights cause in the 1950s. Yet for readers of 1973 , Black Power, ubiquitous in the American news media throughout the late 1960 s and early i 970 s, would have been a more immediate cultural referent for the Schwarzkommando. Indeed, Ashe makes this connection in the article quoted above. As noted previously, David Witzling addresses the more particular analogy between the Schwarzkommando and the Black Panther Party, which I explore further in the present article. The Schwarzkommando narrative can be read, I suggest, as a sort of countercultural cautionary tale offering theories on the causes of the failure of the youth movements of the 1960s, and the BPP in particular, to ultimately transform American society - an appropriate subtitle might be "How Not to Run a Revolution."

Revolutionary suicide reappears in connection to the Schwarzkommando through insistent suggestions that Enzian is planning to fire himself in the V-2 rocket he will construct. He seems to believe that committing suicide in this way will improve the rocket launch's chances of effecting a return to "the Center." Given the novel's examination of the subject described above, it seems legitimate to consider whether Enzian's prospective self-sacrifice fits the rubric for revolutionary suicide detailed by Newton. At first, it appears that it does. Enzian, at least, seems convinced that this ritualized martyrdom offers him "the possibility, if not the probability, of changing intolerable conditions" for his community. Yet the tone of the commentary which Pynchon builds around the event is overwhelmingly negative, and it becomes clear that Enzian's death will actually be much more reactionary than revolutionary. Indeed, the very fact that in the rocket launch Enzian will certainly die excludes his sacrifice from the category of revolutionary suicide. As Judson L. Jeffries emphasizes, for Newton, "to take one's own life or to quit one's station willfully is a cop out - the ultimate expression of Reactionary Suicide." ${ }^{29}$ To quote Newton, "We have such a strong desire to live with hope and human dignity that existence without them is impossible. When reactionary forces crush us, we must move against these forces, even at the risk of death" $(R S 5)$. The point is to risk death, not to seek it. Enzian, the narrator implies, is being seduced towards his own death, a situation turned to tragicomic effect in the song "Sold on Suicide" (GR 320). This seduction has

${ }^{29}$ Judson L. Jeffries, Huey P. Newton: The Radical Theorist (Jackson: University Press of Mississippi, 2002), 43. 
been achieved in part via the machinations of the sinister Ombindi, leader of the Empty Ones, another Zone-Herero faction advocating complete tribal suicide. Such internal racism is, in fact, echoed to some extent in Tchitcherine's support for revolutionary suicide, given that he is on a mission to kill Enzian, his half-brother, despite a number of essential similarities between the pair.

Gravity's Rainbow presents the reader with reactionary suicide masquerading as revolutionary suicide, and in doing so the novel questions the practicality of Newton's doctrine, and its resistance to misinterpretation. Since taking one's own life goes directly against the spirit of the theory, to name it "suicide," albeit "revolutionary," is deeply problematic. Furthermore, in emphasizing that Enzian's suicide would play nicely into the hands of those wishing for his personal destruction and/or that of his community, Pynchon suggests that the theory might surreptitiously channel unconscious self-hatred. But Pynchon's Schwarzkommando narrative contains more than a critique of revolutionary suicide in practice-it also incorporates a commentary on the problematics of revolutionary leadership, with specific reference both to the Black Panther Party and to other 1960s protest movements, given that the Schwarzkommando also represent oppositional groups more generally.

Enzian is a failure as leader of the Schwarzkommando, who fade out of the novel before their dubious revolutionary premise is tested - much as the BPP faded out of American history in the early I 970 s without having achieved their aims. Through the character of Enzian, Pynchon suggests that oppositional leaders can fail to lead effectively due to an excessive self-interest and lack of connection to those they are committed to lead. Enzian does not have the requisite "I am we" mentality; instead the reader finds repeated references to the unattenuated strength of his individual ego, instances of disharmony between himself and his community, and an accumulation of fears and doubts as the day of the rocket launch approaches. Following an attack by the Empty Ones upon his pregnant cousin, Christian, one of Enzian's closest allies, rages against his leader's self-centredness: "you don't care about me, you don't care about my sister, she's dying out there and you just keep plugging her into your equations - you - play this holy-father routine and inside that ego you don't even hate us, you don't care, you're not even connected any more" (GR 525 ). Later, talking about the consequences of his relationship with Captain Weissmann ("Whiteman," in German), who brought him to Europe from Africa as his homosexual lover, Enzian imagines himself looking out over the "Rocket state" he now belongs to, and explains that he has become an "estranged figure at a certain elevation and distance ... who has lost everything else but this vantage" (GR 660). A few days before the rocket launch, Enzian finally seems to realize the depths of this estrangement, as he wonders, "Who 
will believe that in his heart he wants to belong to them out there, the vast Humility sleepless, dying, in pain tonight across the Zone?" (GR $73 \mathrm{I}$ ). Indeed, the Zone-Herero seem to have become overtly hostile to their stony-faced leader, causing Enzian to feel, "His people are going to demolish him if they can" $(G R$ 73I $) .30$

A similar disconnection within the Black Panther leadership was put forward by Huey P. Newton himself as a major factor in the group's decline, and it may be that Pynchon intends a deliberate analogy between Enzian and the figure to whom Newton's criticism attached itself in particular, Eldridge Cleaver. Cleaver was an ex-con who had been recruited to the party in 1967. As a result of the apparently FBI-led imprisonment of Newton and Seale, Cleaver rose through the ranks at a critical time in the development of the organization. Described in a Los Angeles Times obituary as "the era's embodiment of black militancy," ${ }^{1}$ Cleaver was accused by Newton of almost single-handedly destroying the BPP, and was formally expelled from the group in $197 \mathrm{I}$. For Newton, Eldridge "lived in a fantasy world" ( $\left.R S_{135}\right)$ in which the realities of the community's needs were ignored:

Long before Eldridge's actual defection from the Party he had taken the first steps of his journey into spiritual exile by failing to identify with the people. He shunned the political intimacy that human beings demand of their leaders. When he fled the country, his exile became a physical reality. Eldridge had cut himself off from the revolutionary's greatest source of strength - unity with the people, a shared sense of purpose and ideals. His flight was a suicidal gesture, and his continuing exile in Algeria is a symbol of his defection from the community on all levels-geographical, psychological, and spiritual. ( $R S$ 33I $)$

For Cleaver, a lack of identification with the people lurks behind the actions of a leader whose apparent attempts to help ultimately express a desire to escape real responsibility while creating a myth of self, and this is also largely true of Enzian, although his negative characteristics have so far been neglected in criticism. Thanks to his apparent nobility, dignity, and overall charisma (not necessarily a positive quality in this era of Weberian routinization ${ }^{32}$ ), Enzian garners considerable reader sympathy. Cleaver too

${ }^{30}$ This phrase has often been discussed critically with reference to the life of Christ. See, for example, Kathryn Hume, "Views from Above, Views from Below: The Perspectival Subtext in Gravity's Rainbow," American Literature, 60, 4 (Dec. 1988), 625-42. While I agree with such interpretations in that Christ is clearly an important referent here, I suggest that the contemporary sociopolitical frame is equally, if not more, important to a rounded understanding of the Schwarzkommando narrative.

${ }^{31}$ Jenifer Warren, "Former Black Panther Eldridge Cleaver Dies at 62," Los Angeles Times, 2 May i 998, I.

${ }^{32}$ Pynchon's concept of charisma is closely tied to his reading of Max Weber. William M. Plater has written on this subject in The Grim Phoenix: Reconstructing Thomas Pynchon (Bloomington and London: Indiana University Press, 1978). 
was charismatic, and despite Newton's misgivings met approval with other youth movements of the 1960s, even, for some, achieving the status of "folk hero." 33 Very little criticism of individual Panthers or of their particular strategies was offered up by other revolutionary groups active at the time; rather, as Todd Gitlin of the SDS has pointed out, "At a time when the hierarchy of sacrifice certified revolutionary virtue, the Panthers were irresistible allies." ${ }^{4}$ I suggest that Pynchon aims to redress the balance somewhat in Gravity's Rainbow.

Pynchon also destabilizes, as we have seen, the oversimplistic equation of martyrdom with "revolutionary virtue." Of particular importance to the commentary offered via the Schwarzkommando narrative on the Black Panthers, and the protest movements of the late 1960 s more generally, is the question of violence. A new attitude towards violence characterized the majority of these movements. Student organizations which had initially been dedicated to peaceful protest also began to appreciate the power of physical force (or the threat thereof) in this period. In its representation of the Panthers, Gravity's Rainbow has seemed to offer support for the views of Newton, and although Newton, in cofounding the BPP, initiated the idea of presenting a militant front and carrying firearms, he was quick to realize that "weapons and uniforms set [the Panthers] apart from the community" (RS 329). The most essential and destructive element of Cleaver's philosophy, according to Newton, was his obstinate clinging to the notion that revolution "could take place only through violence, by picking up the gun and storming the barricades." For Newton, this "obsessive belief alienated [Cleaver] more and more from the community. By refusing to abandon the position of destruction and despair, he underestimated the enemy and took on the role of the reactionary suicide" ( $R S$ 33 I ). Newton's statements make it clear that Cleaver's brand of violence was very different from that advocated within the doctrine of revolutionary suicide. It was a form of violence which, rather than expressing a deep connection with the community, actually worked to drive the revolutionary community apart. Involving far more masculinist posturing than desperate struggle, it was a violence which sought to mimic that of the oppressive regime, to accumulate power to the self. Unfortunately, it was this type of violence which spread throughout the radical left towards the end of the decade, fragmenting the movement and leading to numerous confrontations with police forces, to the formation of groups such as the Weather Underground, and to tragedies such as the killings at Kent State University. 
Cleaver's glorification of "the intense moment when combatants stood at the brink of death" (RS 330) recalls Enzian's elevation of his own moment of sacrifice to the status of a martyrdom. For Enzian the rocket is a mode of deliverance just as the rifle was for Cleaver. The connection between the Panthers' attachment to firearms and the Schwarzkommando's rocket worship is discussed by David Witzling, ${ }^{35}$ who argues that Pynchon's treatment of the latter suggests a belief that technologies like advanced weaponry are "bound to continue serving an existing hegemony rather than marginalized groups." ${ }^{6} 6$ Yet while it is true that such weapons, in their ability to divorce subject from object and to make death abstract, better suit the scientific rationalism of the incumbent authorities than oppositional groups, Witzling misses a bigger point here. It is not so much the rocket itself that is a problem for the Schwarzkommando, but the fact that they worship it. The rocket, embodying the power of the ruling class, is lusted after by those who wish to challenge and coopt that power. Moreover, this idolatry is combined with deeply unrealistic ideas about what the firing of the rocket can achieve. For Pynchon, as I have suggested, weapons can be used as effective tools of rebellion by oppositional groups, but violence must always be a despised last resort rather than a readily adopted means of selfaggrandizement.

Witzling also considers Pynchon to be exploring the "self-conscious" use of weaponry by oppressed peoples. ${ }^{37}$ However, Pynchon's Schwarzkommando narrative emphasizes the failure of such appropriations to be adequately selfconscious. In fact, he does not seem to place the blame for the misuse of violence in the late 1960 on only, or even primarily, with those individuals who adopted or advocated it. Enzian's failure as a leader is marked out as unwitting; like Cleaver, he believes he is helping those who look up to him as a leader. The reader's awareness of this heightens the pathos of Enzian's situation, as in his poignant realization that his people "are going to demolish him if they can," and contributes to the sympathy he attracts as a character. The narrator makes it clear that Enzian's misguided notion of effective political activism is in substantial part down to the negative influence of the Western society he lived in for many years as a young man. Through Enzian's personal history, Pynchon builds a characteristically countercultural critique, showing how an initial attraction towards forms of power generated by cultures of "Analysis and Death" $(G R 722)$ can lead to the development of an essentially selfdestructive impulse.

\footnotetext{
${ }^{35}$ David Witzling, Everybody's America: Thomas Pynchon, Race, and the Cultures of Postmodernism (New York: Routledge, 2008), i 68.

${ }^{36}$ Ibid., 159.
} 
Just as the Counterforce find themselves coopted by "The Man," so the Zone-Hereros' "tribal unity" is merely a pretence, an attempt to "make believe the Christian sickness never touched us, when everyone knows it has infected us all, some to death" (GR 320-2I). That Enzian is thinking of his relationship to Weissmann when he pictures himself as an "estranged figure" underscores the importance of the role white Western society has played in that estrangement. The narrator recounts how, leaving behind him the warmer, more balanced community of his South West African tribe, Enzian was brought to Nazi Germany, the apotheosis of analytical culture, a "Kingdom of Death" (GR 722), and indoctrinated by Weissmann and the other Nazis into a peculiar logic of love which "had to do with masculine technologies, with contracts, with winning and losing. Demanded, in his own case, that he enter the service of the Rocket" (GR 324). The connection made here between Enzian's fascination with the rocket and his love for Weissmann is further clarified in a discussion around Weissmann's codename, "Blicero." The reader is told that Weissmann's adoption of Blicero as his SS pseudonym was intended to indicate to Enzian "yet another step to be taken toward the Rocket" (GR 322). With its etymological links to death, bleaching and blankness, "Blicero" sets up a concurrence between whiteness, death and the rocket, an analogy which has worked to push Enzian "toward a destiny he still cannot see past this sinister cryptography of naming, a sparse pattern but one that harshly will not be denied, that cries and nags him on stumbling as badly as 20 years ago" $(G R$ 322). It is this alliance which will engender the nightmarish "Rocket state" which Enzian envisages himself presiding over, a society based on the worship of technology, controlled by corporate interests - essentially Pynchon's dystopian vision of the future. That Enzian is indeed corrupted by the logic of this degraded Western culture is demonstrated by the specifics of Christian's attack as described above: Christian accuses Enzian of indifference to the humanity of his sister, of merely, analytically, "plugging her into your equations," and describes him as playing the part of a holy father, which corresponds to Pynchon's recurrent criticism of the complicity of certain forms of Christianity, particularly Puritanism, in the development of the "Western" mindset and the oppression of Third World peoples.

All in all, then, those sections of Gravity's Rainbow which deal with the Black Panther Party express support for the stated aims of the group, and especially for the ideology articulated by Huey P. Newton, but also demonstrate a keen awareness of the various ways in which these ideals were betrayed, leading to the failure of the organization's plans to revolutionize their society. Going beyond the well-known role of the FBI in bringing down the Panthers, the novel draws readers' attention to subtler factors at play within the BPP and in other contemporary revolutionary groups, warning 
future revolutionaries to maintain a clear unity of means and ends, to question the motives of those who seek to lead and of those who advocate violence, and not to accept political theory or proposals for action without due thought and debate. This is why Pynchon imposes on each of his readers the onus of research and interpretation. As Newton put it, there must be "dialogue, dialectical struggle, or struggle through words" towards "the next advance man will make; that he will put down the club." ${ }^{8}$

${ }^{38}$ Huey P. Newton, “A Spokesman for the People: In Conversation with William F. Buckley," I I Feb. 1973, in The Huey P. Newton Reader, 282. 